\title{
The Influence of Used Good-Based Learning Media on the Value of Chracter Education and Student's Motivation to Study
}

\author{
Rumiris Lumban Gaol ${ }^{\mathbf{1}}$, Anton Sitepu ${ }^{2}$ \\ ${ }^{1,2}$ Universitas Katolik Santo Thomas Medan, Indonesia \\ rumiris20lumbangaol@gmail.com,antonsitepu30@gmail.com
}

\begin{abstract}
The purpose of this study was to see the effect of used goods-based learning media on the value of character education and student motivation. Something that can give effect or result from an action so as to bring a result of an effort or action taken, in this case the effect can be seen from achieving a specific instructional goal that has been planned. The place of this research is SD Sinar Pembaharuan Hidup. The subjects of this study were 35 students of grade VSD. Based on the theoretical study and data analysis, 1) based on the test criteria, the three variables have an average value of at least 3 , in this case it is categorized as good. 2) the significance test of 0.005>0.000, this test shows the effect of used goods-based division media on the value of character education and student motivation, 3) the $f$-value test shows that f-count $>f$-table is $4.192>3.29$ and 4.757> 3,29 This statement shows the influence of learning media on the value of character education and student learning motivation.
\end{abstract}

Keywords

learning media; character education value; learning motivation

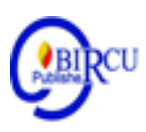

\section{Introduction}

Education is a conscious and planned effort to create an atmosphere of learning and the learning process so that students actively develop their potential to have religious spiritual strength, self-control, personality, intelligence, noble character, and skills needed by themselves, society (National, 1982). Sitorus (2019) states that Education is one way to produce quality Human Resources (HR) with experience changes in knowledge, skills and attitudes. These changes can be a capital to improve selfcompetence in facing the era of globalization that always undergo the change.

The development of technology and information has had a significant influence on society. To create an atmosphere of learning and an active learning process, learning strategies are needed both in applying models, learning methods, learning resources and learning media. Learning aims so that students are able to gain understanding and knowledge through a process of new experiences gained during learning thereby being able to improve student skills. To get this new experience, an appropriate learning resource and media are needed as a tool to make it easier for educators to convey the content of learning material according to the child's abilities, character and student learning environment (Tafonao, 2018).

Learning is the process of delivering learning material that is carried out through interactions with one another, namely between educators and students in the learning environment. The ability of students' level of understanding of learning material is different from one another, therefore teachers or educators must be able to overcome any weaknesses of students in the learning process both how to convey learning material and the media used in learning, in other words learning is a combination of educators and students. , learning 
material sources, learning tools, study room, learning process in order to achieve learning objectives (Hamalik, 2002). Gagne said that media are various types of components in the student environment that can stimulate them to learn. Where the components in the student environment relate to the real world of students.

\section{Review of Literatures}

Learning media are tools or components that are used to convey the message of a learning material in the learning process. Student understanding is holistic or comprehensive, meaning that the level of understanding is in accordance with what is seen and heard that is understood without being analyzed first. Therefore, an effective learning resource and learning media is the environment around students (Istialina, 2016). Therefore the role of the teacher must be able to create new experiences in the learning process by bringing students into the real world of students, namely the environment around students (Munadi, 2008). At present it is known that e-learning based education has become a distinct trend even as a selling point for educational institutions especially distances education Siburian (2020).

According to Sitorus (2020) learning management strategies are very important in the overall learning strategy system. However the planning of the organizing strategy and the learning delivery strategy are good, but if the management strategy is not considered, the effectiveness of learning. Application of learning strategies to a teacher who will be able to successfully implement these strategies in the implementation of learning in class. The success of a teacher implementing a learning strategy is very dependent on the teacher's ability to analyze the existing learning conditions, such as learning objectives, student characteristics, learning resource constraints, and characteristics of the field of study.

One of the educational reforms includes a view of the existence of students who are integrated with their socio-cultural environment and in turn will foster individuals as individuals and cultured independent members of society. The environment is an effective learning media and learning resource because it is a real world where students grow and develop in their environment, besides that it is also an environment where children's social growth includes forming children's characteristics. (Wakhidah \& Adiarti, 2014). Learning media made from the student environment is using used items from the environment around students such as used cardboard, plastic bottles, cans, paper and plastic. These used goods are usually hunted materials that are always sought after by the surrounding community, including students who are one of the livelihoods of the local community so that they can be sold to the shelter. These used goods are designed to be attractive learning media according to the learning material and student characteristics (Maghfirah, 2019). The learning material carried out in this study is thematic learning with the theme "Our Friends' Environment" in the sub-themes of 1) humans and the environment, 2) environmental changes and, 3) environmental conservation efforts. The learning media that is used as a tool used to make it easier for researchers to deliver learning material is to make learning media based on used goods that are around students on the water cycle material and scale images. In the material on the social diversity of the community and the economic role of the community using the surrounding environment as a learning resource. The social diversity of the people in the research area varies while the economy of the community is in the middle to lower economy.

Utilizing the environment as a learning medium has its own impact on children, including cultivating character values. Raka said that education for character building basically includes the development of substances, processes and an atmosphere or environment that inspires, provides encouragement, and makes it easier for someone to 
develop good habits in everyday life. The habits that arise will develop based on one's awareness, belief, sensitivity and attitude. Thus, the character is inside-out, in the sense that the behavior that develops into a good habit occurs because of an inner push, not because of external coercion (Siti Irene Astuti D, 2010) The habits that arise will develop based on awareness , one's beliefs, sensitivities, and attitudes. Thus, the character is inside-out, in the sense that the behavior that develops into good habits occurs because of an internal push, not because of external coercion (Siti Irene Astuti D, 2010).

Children's character is shaped by the environment around students, both the family environment, the school environment and the community environment. Ratnawati (Mustoip 2018) said that carrier factors include factors from heredity, namely parents and family environment, and environmental factors including the surrounding environment or community environment. Character is a trait attached to a person who is related to the creator, himself, his family, and the people around him including the wider community. Zubaedi (2013) states that the factors that affect children's character education are: 1) instinct factors (instinct). Instinct is a set of traits that humans are born with. Psychologists explain that instinct (instinct) serves as a driving motivator that drives behavior. 2) Custom factors. Adat / habit is every act and deed of a person which is repeated in the same form so that it becomes a habit, such as dressing, eating, sleeping, and exercising. 3) Heredity. Directly or indirectly, offspring greatly influences the character education or attitude of a person. The basic characteristics of children are a reflection of the basic qualities of their parents. 4) Milieu or environmental factors. One of the aspects that contribute to the formation of a person's attitude and behavior is the milieu (environment) factor. Milieu means something that encompasses a living body, includes land and air, while the human environment is what surrounds it, such as land, ocean, air and society. Character education will have an impact if someone is able to apply what values are in it. The value of character education is respect, care for the environment, love to read, love peace, social care, friendly / communicative, respect creation, love for the motherland, national spirit, curiosity, democratic, tolerance, honesty, discipline, creative, hard work, religious, independent (Subianto, 2013).

The purpose of learning media is to provide learning stimulation to open the concept of student understanding of the learning material, so that stimulation of student learning is able to provide learning motivation for students, so that with this motivation students get new experiences and are able to understand learning material. Hamalik (Sri et al., 2014) said that motivation is a change in energy in a person's personality which is marked by the emergence of feelings and reactions to achieve goals. The higher a person's motivation, the higher the level of achievement obtained. The high desire of students to understand learning material is due to the encouragement of students to learn in order to achieve maximum results. Motivation to learn (Fauziah et al., 2017) is an encouragement that arises from a person and plays an active role in increasing his understanding of learning material so that he is able to achieve the expected goals and in the end can increase achievement. Sanjaya said that the function of motivation in learning is to encourage students to be active in learning and direct students to achieve their goals, namely understanding learning material (Emda, 2018).

Motivation does not come by itself, but motivation needs to be built in someone. There are many factors that motivate students to not have learning motivation, including the community environment, parental support, infrastructure, teachers are not maximal in combining models and learning media, teachers teach one way, namely the lecture model so that students experience boredom in the learning process and are ultimately unable reach learning objectives. 
Researchers made observations of students of SD Sinar Pembaharuan Hidup, based on these observations it was found that the lack of motivation of students to learn so that students get bored while studying and students are lazy to go to school. The cause of students being bored learning in class is because teachers still use the lecture method when learning and do not use learning media. Another thing that causes students to be lazy to go to school and not want to go to school is because students prefer to look for used goods together with their peers that can be sold so that students can get money. The social economy of the community is at the middle to lower level, which is crowded with farmers and traders, this can affect student motivation. Student learning motivation is influenced by several things both from students and from outside, namely students' aspirations and aspirations, student abilities, student conditions and student environmental conditions (Emda, 2018)

Researchers try to bring used items that are always sought after in the student community to be sold into the classroom to be used as learning media. Hamalik (Soenarko et al., 2018) said that "The use of instructional media in the teaching and learning process can generate new desires and interests, generate motivation and stimulation of learning activities, and even bring psychological influences on students". Used goods are sourced from the environment around students who are close to the real world of students so that when used as a medium of learning, students will find it easier to embed concepts on learning so that it makes it easier for students to achieve learning goals.

In thematic learning learning objectives will be easily achieved if the learning is meaningful where meaningful learning is obtained by students if the teacher brings the concept of learning into the student's real world, namely the surrounding environment. Majid (Novika Auliyana et al., 2018) stated that an integrated thematic learning allows students either individually or in groups to explore and find holistic, authentic, and meaningful concepts.

The purpose of this study was to see the effect of used goods-based learning media on the value of character education and student motivation. Something that can give effect or result from an action so as to bring about a result of an effort or action taken, in this case the effect can be seen from achieving a specific instructional goal that has been planned.

\section{Research Method}

This research method is a quantitative method of experimental type, namely a study that seeks to find the effect of certain variables on other variables under tightly controlled conditions. Observation data collection techniques and questionnaires. Sugiyono 2015 said that a questionnaire or questionnaire is a data collection technique by providing or distributing a list of questions to respondents. In this study, there were 4 answers using the Likert scale. The Likert scale is used to measure the attitudes, opinions and perceptions of a person or group. The questionnaire used in this study used 4 alternative answers to the positive statement disagree $=1$, disagree 2 , agree $=3$, strongly agree $=4$. On the negative statement agree $=4$, disagree 3 , agree $=2$, strongly agree $=1$. The place of this research is SD Sinar Sinar Pembaharuan Hidup. The subjects of this study were 35 students of grade V SD. 


\section{Discussion}

\subsection{Learning Media Based on Used Goods}

Media is a word derived from the Latin medius, which literally means middle, intermediary or introduction (Prasasti, 2019). Assessment indicators for aspects of learning based on used goods that have been declared valid are given to students to see the eligibility criteria for used goods as learning media. After that, a statement in the form of a questionnaire will be distributed to students to see the effect of the learning media on the value of character education and student motivation.

Table 1. Category of Used Goods Based Learning Media

\begin{tabular}{|c|l|c|c|}
\hline ASPECT & $\begin{array}{l}\text { ASSESSMENT } \\
\text { INDICATOR }\end{array}$ & AVERAGE & PERCENTAGE \\
\hline $\begin{array}{c}\text { Learning media } \\
\text { based on used } \\
\text { goods }\end{array}$ & $\begin{array}{l}\text { 1. The Nature of Learning } \\
\text { Media }\end{array}$ & 3.2 & $80 \%$ \\
\cline { 2 - 4 } & $\begin{array}{l}\text { 2. Learning Media } \\
\text { Components }\end{array}$ & 3.4 & $85 \%$ \\
\hline
\end{tabular}

Based on the analysis of the assessment indicators in the table above, the average value in the essence of learning media is 3.2 in good categories and the average value on the learning media component is 3.4 in good categories.

\subsection{Character Education Value}

The value of character education that will be distributed through questionnaires to students is seen based on good categories.

Table 2. Category of Character Education Value

\begin{tabular}{|c|l|l|l|}
\hline ASPECT & $\begin{array}{l}\text { ASSESSMENT } \\
\text { INDICATOR }\end{array}$ & AVERAGE & PERCENTAGE \\
\hline \multirow{3}{*}{$\begin{array}{c}\text { Value } \\
\text { Of Character } \\
\text { Education }\end{array}$} & Environmental care & 3.4 & $85 \%$ \\
\cline { 2 - 4 } & Creative & 3.3 & $82.5 \%$ \\
\cline { 2 - 4 } & Independent & 3.2 & $80 \%$ \\
\cline { 2 - 4 } & Curiosity & 3.2 & 80 \\
\cline { 2 - 4 } & Responsible & 3.0 & $75 \%$ \\
\hline
\end{tabular}

Based on the results of the analysis, the results are as in the table above. So the value of character education that is categorized as good is caring for the environment, creative, independent, curiosity and independent.

\subsection{Student Learning Motivation}

Indicators of student learning motivation questionnaires that will be distributed and answered by students in good categories.

Table 3. Categories of Student Learning Motivation

\begin{tabular}{|c|l|c|c|}
\hline ASPECT & $\begin{array}{l}\text { ASSESSMENT } \\
\text { INDICATOR }\end{array}$ & AVERAGE & PERCENTAGE \\
\hline Motivation & $\begin{array}{l}\text { 1. The ideals and aspirations } \\
\text { of }\end{array}$ & 3.1 & $77.5 \%$ \\
\hline
\end{tabular}




\begin{tabular}{|l|l|c|c|}
\hline \multirow{4}{*}{ to learn } & students & & \\
\cline { 2 - 4 } & 2. Student Abilities & 3.2 & $80 \%$ \\
\cline { 2 - 4 } & 3. Student conditions & 3.3 & $82.5 \%$ \\
\cline { 2 - 4 } & 4. Environmental Conditions & 3.5 & $87,5 \%$ \\
\hline
\end{tabular}

The assessment of the indicators of learning motivation is shown in the table above, based on the assessment criteria which are above the average of 3.27 which are in the good category.

Instruments that have been measured based on the level of validity and feasibility categories are then distributed to students in the form of a questionnaire according to predetermined criteria. To see the effect of the three variables, namely used goods-based learning media, the value of character education and student learning motivation. Data analysis will be carried out by means of a regression test with the help of SPSS.

Table 4. Multivariate Tests ${ }^{\mathrm{a}}$

\begin{tabular}{|l|l|l|l|l|l|l|}
\hline Effect & Value & F & $\begin{array}{l}\text { Hypothesi } \\
\text { s df }\end{array}$ & Error df & Sig. \\
\hline \multirow{4}{*}{$\begin{array}{l}\text { learning } \\
\text { Media }\end{array}$} & Pillai's Trace & 1.067 & 4.408 & 14.000 & 54.000 & .000 \\
\cline { 2 - 7 } & Wilks' Lambda & .217 & $4.251^{\mathrm{b}}$ & 14.000 & 52.000 & .000 \\
\cline { 2 - 7 } & $\begin{array}{l}\text { Hotelling's } \\
\text { Trace }\end{array}$ & 2.293 & 4.094 & 14.000 & 50.000 & .000 \\
\cline { 2 - 7 } & $\begin{array}{l}\text { Roy's Largest } \\
\text { Root }\end{array}$ & 1.234 & $4.761^{\mathrm{c}}$ & 7.000 & 27.000 & .001 \\
\hline
\end{tabular}

a. Design: Intercept + MediaPembelajaran

b. Exact statistic

c. The statistic is an upper bound on $\mathrm{F}$ that yields a lower bound on the significance level.

Based on the table above, it is found that the sig value $<0.05$ is $0.00<0.05$. Then from the question it can be concluded that there is an influence between the variables.

Table 5. Tests of Between-Subjects Effects

\begin{tabular}{|l|l|l|l|l|l|l|}
\hline Source & Dependent Variable & $\begin{array}{l}\text { Type III df } \\
\text { Sum } \\
\text { Squares }\end{array}$ & $\begin{array}{l}\text { Mean } \\
\text { Square }\end{array}$ & F & Sig. \\
\hline \multirow{5}{*}{ Corrected Model } & Motivation to learn & $68.887^{\text {a }}$ & 7 & 9.841 & 4.757 & .001 \\
\cline { 2 - 7 } & $\begin{array}{l}\text { Value of Character } \\
\text { Education }\end{array}$ & $47.676^{\text {b }}$ & 7 & 6.811 & 4.192 & .003 \\
\hline Intercept & Motivation to learn & 19357.173 & 1 & $\begin{array}{l}19357.1 \\
73\end{array}$ & $\begin{array}{l}9357.05 \\
8\end{array}$ & .000 \\
\cline { 2 - 8 } & $\begin{array}{l}\text { Value of Character } \\
\text { Education }\end{array}$ & 18498.929 & 1 & $\begin{array}{l}18498.9 \\
29\end{array}$ & $\begin{array}{l}11386.1 \\
19\end{array}$ & .000 \\
\hline learning Media & Motivation to learn & 68.887 & 7 & 9.841 & 4.757 & .001 \\
\cline { 2 - 8 } & $\begin{array}{l}\text { Value of Character } \\
\text { Education }\end{array}$ & 47.676 & 7 & 6.811 & 4.192 & .003 \\
\hline Error & Motivation to learn & 55.856 & 27 & 2.069 & & \\
\hline
\end{tabular}




\begin{tabular}{|l|l|l|l|l|l|l|}
\hline & $\begin{array}{l}\text { Value of Character } \\
\text { Education }\end{array}$ & 43.867 & 27 & 1.625 & & \\
\hline \multirow{3}{*}{ Total } & Motivation to learn & 34822.000 & 35 & & & \\
\cline { 2 - 8 } & $\begin{array}{l}\text { Value of Character } \\
\text { Education }\end{array}$ & 34412.000 & 35 & & & \\
\hline \multirow{2}{*}{ Corrected Total } & Motivation to learn & 124.743 & 34 & & & \\
\cline { 2 - 5 } & $\begin{array}{l}\text { Value } \\
\text { Education }\end{array}$ & 91.543 & 34 & & & \\
\hline
\end{tabular}

a. $\mathrm{R}$ Squared $=.552($ Adjusted R Squared $=.436)$

b. $\mathrm{R}$ Squared $=.521$ (Adjusted R Squared $=.397$ )

Data analysis was carried out based on the above table, that the value of $\mathrm{f}$-count $<\mathrm{f}$ table, namely 4.757> 3.29, this statement shows the influence of learning media on learning motivation. Meanwhile, learning media with learning motivation also shows an influence with a value of $4.192>3.29$.

\section{Conclusion}

Based on the theoretical study and data analysis, 1) based on the test criteria, the three variables have an average value of at least 3, in this case it is categorized as good. 2) the significance test of $0.005>0.000$, this test shows the influence of used barag-based division media on the value of character education and student motivation, 3) the f-value test shows that $\mathrm{f}$-count> f-table is $4.192>3.29$ and 4.757> 3,29 This statement shows the influence of learning media on the value of character education and student motivation.

\section{References}

Emda, A. (2018). Position of Student Learning Motivation in Learning. Lanthanide Journal, 5 (2), 172. https://doi.org/10.22373/lj.v5i2.2838

Fauziah, A., Rosnaningsih, A., \& Azhar, S. (2017). The Relationship Between Learning Motivation And Learning Interest Of Class Iv SDN Poris Gaga 05, TANGERANG CITY. JPSD Journal (Journal of Elementary School Education). https://doi.org/10.26555/jpsd.v4i1.a9594

Istialina. (2016). Utilization of the environment as a learning resource on the sub-theme of animals and plants in my home environment for class iv to public 3 jeumpa, Bireuen district. PGSD Study Program Student Scientific Journal, 1 (1), 59-68. https://media.neliti.com/media/publications/188662-ID-peman]-lingkungan-sebagaisumber-be.pdf

Maghfirah, S. (2019). Utilization of Used Goods in Improving Children's Fine Motor Skills. Ațālunā: Journal of Islamic Early Childhood Education. https://doi.org/10.32505/atfaluna.v2i1.938

Munadi, Y. (2008). Learning Media (a new approach). Jakarta: Echoes of Persada Press.

National, U. S. P. (1982). Introduction and Aim of the Study. Acta Pædiatrica, 71, 6-6. https://doi.org/10.1111/j.1651-2227.1982.tb08455.x

Novika Auliyana, S., Akbar, S., \& Yuniastuti. (2018). Application of Integrated Thematic Learning in Elementary Schools. Journal of Education: Theory, Research, and Development, 3 (12), 1572-1582. 
Prasasti, T.I., Solin, M., and Hadi, W. (2019). The Effectiveness of Learning Media Folklore Text of North Sumatera Based on Blended Learning by 10th Grade Students of Vocational High SchoolHarapan Mekar-1 Medan. Budapest International Research and Critics in Linguistics and Education (BirLE) Journal Vol 2 (4): 480-490.

Siburian, S., Hutagalung, S.M., and Daulay, S. (2020). Development of Adobe Flash CS6 Learning Media in Short StoryBased on Learning Text of Advanced Local Community of Batak Toba Students in Tanjungmorawa. Budapest International Research and Critics in Linguistics and Education (BirLE) Journal Vol 3 (1): 591-599.

Siti Irene Astuti D. (2010). Holistic and Contextual Approach in Overcoming Character Crisis in Indonesia. 1 (3), 41-58. https://doi.org/10.21831/cp.v1i3.234

Sitorus, H.V., Nugrahadi, E.W., and Budiarta, K. (2019). The Effect of Learning Strategy and Thinking Ability on The Students' Learning Outcomes in Economics Subject of XI Social Students in Senior High School State 1 in Pematang Siantar. Budapest International Research and Critics in Linguistics and Education (BirLE) Journal Vol 2 (4): 451-460.

Sitorus, L.S., Mardianto, and Matsum, H. (2020). Development of Powerpoint-Based Learning Media on Learning Aqeedah Morals. Budapest International Research and Critics in Linguistics and Education (BirLE) Journal Vol 3 (2): 958-964.

Soenarko, B., Wiguna, F. A., Putri, K. E., \& Primasatya, N. (2018). Training on Making Interactive Learning Media by Using Used Materials for Elementary School Teachers in Cluster 2 Members, Ringinrejo District, Kediri Regency. 1 (2), 96-106.

Sri, K., Ulandari, S., Dibia, I. K., Sudana, D. N., \& Pgsd, J. (2014). Odd Semester V Class Private Village In Buruan Village, Ganesha University Of Education.

Subianto, J. (2013). A. Introduction Education is an effort to improve oneself in all its aspects. Education is an integral part of life. Education comes from the word learn which means to maintain and form training, so education is a usa. Journal of Islamic Education Research, 8 (2), 331-354.

Tafonao, T. (2018). The Role Of Learning Media In Improving Students 'Learning Interest. Journal of Educational Communication. https://doi.org/10.32585/jkp.v2i2.113.

Wakhidah, K., \& Adiarti, W. (2014). The effect of planting conservation values on the caring character of the early childhood environment. BELIA: Early Childhood Education Papers, 3 (2). 